\title{
Analisis Faktor-Faktor Penghambat Guru Dalam Materi Tanggung Jawab, Hak, Dan Kewajiban Pada Siswa Slow Learner
}

\author{
Viya Zakiyatul Mubarokah ${ }^{1}$, Endang Wahju Andjariani ${ }^{2}$ \\ Pendidikan Guru Sekolah Dasar STKIP PGRI Sidoarjo \\ Email: zakiyaviya98@gmail.com ${ }^{1}$ endang.wahyu1818@ gmail.com²
}

\begin{abstract}
Abstrak. Penelitian ini membahas tentang faktor-faktor penghambat guru dalam materi tanggung jawab, hak, dan kewajiban pada siswa slow learner. Bertujuan untuk mengetahui secara umum hasil pelaksanaan pembelajaran dan faktor-faktor yang menjadi penghambat guru dalam Tema 2 materi Tanggung Jawab, Hak, dan Kewajiban pada siswa Slow Learner. Menggunakan jenis penelitian deskriptif kualitatif yaitu penelitian yang menggunakan pemecahan masalah dengan data-data yang ada. Subjek penelitian ini adalah guru kelas, guru pendamping khusus (GPK), dan salah satu siswa slow learner dengan observasi dan wawancara, penelitian di laksanakan pada era pandemi covid19 dengan menerapkan protocol kesehatan. Berdasarkan hasil penelitian pelaksanaan pembelajaran yang dilakukan di SDN Gedangan belum sepenuhnya memberikan pembelajaran yang sama antara siswa reguler dengan siswa Slow Learner. Kurangnya pendampingan GPK untuk siswa Slow Learner dikarenakan hanya 1 minggu 2 kali, dan dalam kegiatan penutup pembelajran guru hanya melakukan evaluasi dan tindakan selanjutnya tanpa ada pengulangan materi yang sudah diberikan.
\end{abstract}

Kata kunci : Faktor-faktor penghambat guru, siswa Slow Learner

Abstract. This research discusses the inhibiting factors of teachers in the subject of responsibility, rights, and obligations of slow learner students. Aims to find out in general the results of the implementation of learning and the factors that hinder the teacher in Theme 2 of the Responsibility, Rights and Obligations of Slow Learner students. Using this type of qualitative descriptive research, namely research that uses problem solving with existing data. The subjects of this study were class teachers, special companion teachers (GPK), and one of the slow learner students with observations and interviews, research was carried out in the Covid19 pandemic era by implementing health protocols. Based on the results of research, the implementation of learning carried out at SDN Gedangan has not fully provided the same learning between regular students and Slow Learner students. The lack of GPK assistance for Slow Learner students is due to only 1 week 2 times, and in closing activities the teacher only conducts evaluation and further actions without repeating the material that has been given.

Key words: Teacher's inhibiting factors, Slow Learner students

\section{PENDAHULUAN}

Pendidikan adalah jembatan untuk seluruh masyarakat indonesia agar mempunyai jalan hidup yang positif dan sangat penting atau wajib untuk diikuti seluruh masyarakat. Pendidikan inklusi adalah layanan pendidikan untuk siswa yang memiliki kebutuhan khusus di sekolah regular seperti di sekolah dasar, sekolah menengah pertama, sekolah menengah keatas maupun sekolah menengah kejuruan yang tergolong luar biasa dalam memberikan pendidikan untuk berkelainan lamban belajar maupun berkesulitan belajar lainnya. (Lay Kekeh Marthan, 2007:145). Pendidikan inklusi adalah

pendidikan yang diselenggarakan untuk menyatukan atau mempersatukan anak-anak berkebutuhan khusus dengan anak-anak reguler pada umumnya untuk belajar bersama (Jauhari Auhad, 2017:29). Anak berkebutuhan khusus adalah anak yang mempunyai kebutuhan khusus tersendiri dalam jenis dan karakteristiknya yang 
membedakan dari anak-anak normal pada umumnya (Mumpuniarti, 2007:17). Slow Learner adalah anak dengan keterlambatan belajar dalam tingkat penguasaan materi dan materi tersebut merupakan syarat untuk kelanjutan belajarnya, sehingga mereka harus sering mengulang materi tersebut (Burton, dalam Sudrajat,2008:18). Undang-Undang Nomor 20 Tahun 2003 Tentang Sistem Pendidikan Nasional, Pasal 5 ayat 1 yang menegaskan bahwa setiap warga negara mempunyai hak yang sama untuk memperoleh pendidikan yang bermutu. Adanya pendidikan inklusi ditengah masyarakat diperkuat oleh undang-undang diatas yang menjadi bukti pendidkan inklusi.

Berdasarkan hasil observasi salah satu siswa ABK Slow Learner di kelas V yang bernama MAR. MAR sangat sulit diajak berbicara terhadap orang yang baru dia kenal, hanya orang-orang yang terdekat saja yang dia respon. Di kelas MAR sangat pendiam dan hanya berteman dengan sesama anak berkebutuhan khusus (ABK) saja. Di kelas MAR didampingi oleh pendampingnya yang sudah disediakan oleh sekolah. Menurut salah satu GPK di sekolah MAR mampu membaca 2 suku kata, tetapi MAR sulit untuk berkonsentrasi. MAR juga kesulitan dalam menulis 2 suku kata atau harus menggunakan contoh tulisan dari pendampingnya.

Melalui wawancara dengan guru kelas dan guru pendamping khusus (GPK) faktor-faktor hambatan dalam pembelajaran yang dialami guru kelas dan guru pendamping khusus (GPK) di SDN Gedangan terbagi menjadi dua, yaitu hambatan intern yaitu (dalam diri siswa) dan hambatan ekstern (dari luar diri siswa). Hambatan intern yang dialami guru yaitu tingkat intelegensi siswa Slow Learner, hambatan ketika memodifikasi pembelajaran tema 2 pada materi Tanggung Jawab, Hak, dan Kewajiban pembelajaran. memodifikasi penilaian, terutama dikelas tinggi, konsentrasi belajar siswa, kemampuan mengolah bahan belajar siswa Slow Learner cenderung lebih rendah dibanding siswa regular, dalam menyimpan hasil belajar, dan Kepercayaan diri yang dimiliki siswa Slow Learner cenderung rendah. Pada hambatan ekstern yang dialami guru yakni kebijakan penilaian pembelajaran berupa menyamakan siswa Slow Learner dengan siswa reguler. Hal ini menghambat karena kemampuan siswa Slow Learner dibawah siswa reguler sehingga dalam mengajar, guru harus mengajar dengan sangat maksimal.

Berdasarkan permasalahan diatas, pelaksanaan pembelajaran yang dilakukan di SDN Gedangan belum sepenuhnya memberikan pembelajaran yang sama antara siswa reguler dengan siswa Slow Learner. Kurangnya pendampingan GPK untuk siswa Slow Learner dikarenakan hanya 1 minggu 2 kali, dan dalam kegiatan penutup pembelajaran guru hanya melakukan evaluasi dan tindakan selanjutnya tanpa ada pengulangan materi yang sudah diberikan.

Berdasarkan latar belakang tersebut, maka peneliti tertarik untuk melakukan penelitian terahadap faktor-faktor penghambat guru dalam materi tanggung jawab, hak, dan kewajiban pada siswa Slow Learner dengan judul penelitian. "Analisis Faktor - Faktor Penghambat Guru Dalam Materi Tanggung Jawab, Hak, Dan Kewajiban Pada Siswa Slow Learner". Maka masalah yang diangkat dalam penelitian ini dapat dirumuskan sebagai berikut.

1. Secara umum bagaimana hasil pelaksanaan pembelajaran Tema 2 pada materi Tanggung Jawab, Hak. dan Kewajiban pada siswa Slow Learner kelas V di SDN Gedangan?

2. Secara umum faktor - faktor apa saja yang menjadi hambatan guru dalam pelaksanaan pembelajaran Tema 2 pada materi Tanggung Jawab, Hak, dan Kewajiban pada siswa Slow Learner kelas V di SDN Gedangan?

\section{METODE PENELITIAN}

Penelitian ini menggunakan jenis deskriptif kualitatif. Penelitian deskriptif kualitatif yaitu penelitian yang menggunakan pemecahan masalah dengan data-data yang ada dan penelitian kualitatif lebih mendeskripsi dan analitik. Penelitian kualitatif yang digunakan pada penelitian ini dimaksudkan untuk menganalisis faktor- 
faktor penghambat guru dalam materi Tanggung Jawab, Hak dan Kewajiban pada siswa Slow Learner secara mendalam dan komprehensif. Penelitian di laksanakan secara offline karena sumber data dapat di ambil lebih mudah di era pandemi covid-19 peneliti dapat menerapkan protokol kesehatan karena hanya membutuhkan 3 orang yang di analisis.

Metode pengumpulan data merupakan cara yang digunakan peneliti untuk mendapatkan data dalam suatu penelitian. Penelitian kali ini peneliti memilih pendekatan penelitian kualitatif maka data yang diperoleh haruslah mendalam, jelas dan spesifik. Peneliti menggunakan teknik pengumpulan data dengan cara observasi, wawancara, dan dokumentasi. Observasi yang dilakukan peneliti agar memperoleh berupa hambatan guru ketika pembelajaran berlangsung. Observasi dilakukan 2 kali di dalam kelas dan 2 kali di dalam kelas khusus anak berkebutuhan khusus (ABK). Penelitian ini menggunakan teknik wawancara terstruktur, yaitu peneliti sudah menyiapkan berupa pertanyaan wawancara yang sudah divalidasi oleh dosen yang berperan sebagai validator untuk menilai kelayakan pertanyaan-pertanyaan wawancara yang digunakan untuk mendapatkan informasi dari subjek. Wawancara ini digunakan agar memperoleh data dan informasi terkait pengalaman dan pengetahuan subjek terkait hambatan ketika pelaksanaan pembelajaran. Dokumentasi dalam penelitian ini digunakan untuk mengumpulkan data dari sumbersumber yang dapat memperkuat proses penelitian.

Deskriptif kualitatif adalah teknik yang digunakan pada penelitian ini, karena dari hasil observasi dan wawancara bersifat uraian. Data yang didapat secara kualitatif akan dianalisa dan menguraikan dalam bentuk deskriptif. Analisis data yaitu kegiatan dalam mencari data-data untuk dijadikan informasi yang dapat dipergunakan untuk mengambil kesimpulan.

Prosedur penelitian pada penelitian ini yaitu tahap yang pertama menentukan topik kegiatan penelitian seperti judul penelitian. Lokasi penelitian yang dijadikan penelitian. Tahap kedua yaitu mengumpulkan data-data yang berkaitan dengan siswa Slow Learner seperti cara pendekatan, metode pembelajaran dan strategi pembelajran yang digunakan. Tahap keempat yaitu peneliti menganalisa data dengan cara observasi, wawancara, dan dokumentasi. Kemudian peneliti mendeskripsikan data sesuai dengan permasalahan dan dapat diambil kesimpulan. Tahap terakhir yaitu membuat laporan berupa penulisan, penyusunan yang sudah dianalisa, dan dapat disimpulkan.

\section{HASIL DAN PEMBAHASAN}

1. Hasil pelaksanaan pembelajaran Tema 2 pada materi Tanggung Jawab, Hak. dan Kewajiban pada siswa Slow Learner kelas V di SDN Gedangan sebagai berikut:

a. Awal Pembelajaran

Pada awal pembelajaran guru melakukan apersepsi untuk menarik perhatian siswa dan memotivasi siswa agar lebih fokus untuk pembelajara. Guru mengapersepsi dengan cara mengajak siswa bercerita, membaca buku, bernyanyi, dan bermain terkait materi pembelajaran yang akan diberikan. Guru juga menyampaikan tujuan meteri pembelajaran tersebut.

b. Inti pembelajaran

Pada kegiatan inti guru meyampaikan materi pembelajaran tema 2 tanggung jawab, hak, dan kewajiban yang sesuai dengan RPP. Guru mejelaskan terkait pengertian tanggung jawab, hak, dan kewajiban. Guru juga memberikan contoh dalam kehidupan sehari-hari siswa untuk bertanggung jawab, mempunyai hak, dan kewajiban siswa ketika berada disekolah, dirumah, maupun di lingkungan masyarakat. Dalam menyampaikan materi guru mengalami hambatan yakni metode dan strategi yang seharusnya sesuai dengan RPP mengelami hambatan. Hambatan itu karena adanya siswa Slow Learner yang mengalami hambatan keterlambatan belajar. Sehingga guru dalam menyampaikan 
materi tidak semua materi disampaikan, karena siswa Slow Learner memiliki keterbatasan dalam menerima informasi.

a. Penutup Pembelajaran

Pada kegiatan ini guru hanya mengevaluasi materi yang diberikan dan menentukan tindakan selanjutnya. Kemampuan siswa Slow Learner dalam mengolah bahan belajar lebih rendah dan membutuhkan bantuan dari siswa reguler atau GPK. Walaupun sudah dibantu oleh GPK atau siswa regular tetap membutuhkan waktu yang cukup lama untuk menerima informasi.

2. Hambatan dalam pembelajaran yang dialami guru kelas V dan GPK di SDN Gedangan terbagi menjadi dua, yaitu hambatan intern ( dari dalam diri siswa) dan hambatan ekstern (dari luar diri siswa).

a. Hambatan intern

Hambatan intern yang pertama yakni intelegensi siswa Slow Learner. Untuk tingkat intelegensi siswa Slow Learner lebih rendah dari siswa regular. Sehingga guru mengalami hambatan dalam memodifikasi kurikulum. Dalam mengajar dikelas guru mengalami hambatan ketika menyampaikan tujuan pemebelajaran, materi pembelajaran, dan penilaian untuk dikelas tinggi

Hambatan yang kedua ketika memodifikasi pembelajaran tema 2 pada materi Tanggung Jawab, Hak, dan Kewajiban. Dalam memodifikasi pembelajaran tema 2 guru mengalami hambatan yakni menentukan materi yang tepat untuk siswa Slow Learner dan siswa regular. Guru tidak bisa memfokuskan terhadap siswa Slow Learner karena akan membuat bosan siswa reguler untuk materi yang terlalu mudah bagi mereka. Sebaliknya untuk siswa reguler juga tidak bisa difokuskan karena materi terlalu sulit untuk siswa Slow Learner. Sehingga guru sedikit kesulitan dalam memutuskan materi yang tepat untuk disampaikan.

Hambatan yang ketiga yaitu modifikasi penilaian, untuk dikelas tinggi. Untuk modifikasi penilaian siswa slow learner dan siswa regular disamakan tingkat kesulitannya dengan memberikan soal yang sama. Namun untuk siswa Slow Learner tingkat kemampuan intelegensinya rendah dibanding siswa reguler. Sehingga guru sangat kesulitan dalam memberikan penilain untuk siswa Slow Learner.

Hambatan yang keempat yaitu pada konsentrasi siswa dalam belajar. Siswa slow learner sangat sulit untuk berkonsentrasi dalam pembelajaran ketika guru menyampaikan materi. Hal ini disebabkan karena siswa Slow Learner mudah tertarik oleh aktifitas teman-temanya yang lain. Jadi, tidak mudah bagi siswa Slow Laearner untuk berkonsentrasi penuh dalam pembelajaran.

Hambatan yang kelima yaitu Kemampuan siswa Slow Learner dalam mengolah bahan belajar sangat rendah dibanding siswa regular. Karena siswa Slow Learner kesulitan dalam mengolah bahan belajar dan membutukan bantuan dari siswa regular atau GPK. Walaupun sudah dibantu siswa slow learner tetap membutuhkan waktu yang cukup lama untuk mengolah bahan belajar, sehingga menghambat dalam proses pembelajaran.

Hambatan yang kelima yaitu pada kemampuan siswa Slow Learner dalam menyimpan hasil belajar terkait dengan ingatan jangka panjang siswa yang sangat rendah. Hal ini sangat menghambat guru dalam pembelajaran karena membutuhkan waktu untuk mengingat kembali materi yang sudah diajarkan.

Hambatan yang terakhir yaitu kepercayaan diri siswa Slow Learner cenderung rendah sehingga menghambat pembelajaran. Ini disebabkan siswa slow learner 
menyadari kemampuannya dibawa siswa regular sehingga siswa Slow Laearner merasa malu ketika unjuk belajar. Kepercayaan diri itu yang menjadi penghambat guru dalam pembelajaran.

b. Hambatan ekstern

Hambatan yang dialami oleh guru diantaranya adalah kebijakan penilaian pembelajaran tema 2 pada materi Tanggung Jawab, Hak, dan Kewajiban yang berlaku. Kebijakan itu yakni terkait penilaian yang harus disamakan antara siswa Slow Learner dengan siswa reguler. Namun kemampuan siswa Slow Learner dibandingkan dengan siswa reguler sangat rendah. Sehingga guru dalam menyampaikan materi harus secara maksimal. agar guru dapat menyamakan penilaian sesuai dengan kebijakan penilaian pada kurikulum yang telah dimodifikasi.

\section{KESIMPULAN}

Hambatan - hambatan yang dialami guru yaitu sebagai berikut :

1. Modifikasi kurikulum dalam penentuan tujuan pembelajaran, memilih materi yang tepat untuk siswa Slow Learner dan siswa reguler, dan penentuan penilaian yang yang tepat untuk siswa Slow Learner dan siswa regular di kelas tinggi.

2. Hambatan guru dalam pembelajaran di SDN Gedangan yang disebabkan oleh faktor intern adalah materi pembelajaran tema 2 pada materi Tanggung Jawab, Hak, dan Kewajiban yang kurang maksimal dan pemilihan metode dan strategi yang tepat untuk siswa Slow Learner dan siswa reguler.

3. Hambatan guru dalam pembelajaran tema 2 pada materi Tanggung Jawab, Hak, dan Kewajiban di SDN Gedangan yaitu kebijakan penilaian pembelajaran tema 2 pada materi Tanggung Jawab, Hak, dan Kewajiban yang berlaku yang disesuaikan dengan kurikulum yang dimodifikasi GPK.

\section{SARAN}

Berdasarkan kesimpulan peneliti memberikan saran sebagai berikut :

1. Guru kelas

Sebaiknya guru kelas berkonsultasi dan bekerja sama terkait hambatan-hambatan yang dialami, sehingga dapat mengatasi hambatan tersebut.

\section{GPK}

Sebaiknya GPK dapat membantu guru kelas dalam menangani hambatanhambatan yang dialami oleh guru kelas, sehingga hambatan-hambatan tersebut bisa segera diatasi.

\section{DAFTAR PUSTAKA}

Jauhari, Auhad. 2017. Pendidikan Inklusi Sebagai Alternatif. Journal Ijtimaiyah,.https://journal.iainkudus. ac.id/index.php/Ijtimaia/article/down load/3099/2308

Marthan, L, K. (2007). Manajemen Pendidikan Inklusif. Jakarta: DIRJEN DIKTI.

Mumpuniarti, Sari Rudiyati, Sukinah, Eka Sapti Cahyaningrum. 2011.Kebutuhan Belajar Siswa Lamban Belajar (Slow Learner) Di Kelas Awal Sekolah Dasar Daerah Istimewa Yogyakarta http://staff.uny.ac.id/sites/default/file s/penelitian/dr-mumpuniartimpd/kebutuhan-belajar-siswalamban-belajar.pdf

\begin{tabular}{|c|c|c|}
\hline Sudrajat. & 2008 & Pendidikan \\
\hline & Berkebutuhan & Khusus \\
\hline & $\begin{array}{l}\text { Belajar (Slow } \\
\text { Gramedia }\end{array}$ & Learner). \\
\hline
\end{tabular}

